\title{
Exploring the use of herbal drugs and advanced supporting techniques for wound healing
}

\author{
Chetan M. Jain ${ }^{1^{*}}\left(\mathbb{0}\right.$, Ravindra L. Bakal ${ }^{1}$, Prashant J. Burange ${ }^{2}$, Nitin I. Kochar ${ }^{3}$, Jagdish V. Manwar ${ }^{4}$, \\ Rahul D. Jawarkar ${ }^{1}$, Minal S. Jaiswal ${ }^{5}$ and Israa Lewaa ${ }^{6}$
}

\begin{abstract}
Background: A wound may define as an interruption within the continuity of the epithelial lining of the skin or mucosa that occurs as a result of physical or thermal damage. Wound healing is an intricate process that is highly synchronized censorious in the management of the protective means of the skin. There are a variety of systemic and local factors that influence wound healing, including oxygenation, inflammation, age, stress, diabetes, nutrition, and nicotine. Hemostasis, inflammation, proliferation or granulation, remodeling or maturation are the principle phases of wound healing.

Main body of the abstract: The authors of the current review attempt to convey that the usage of herbal drugs has extreme importance in the current era. The authors reviewed a total of 38 herbal plants with their mechanism of wound healing and the chemical constituents responsible for it. Hyperbaric oxygen therapy, negative pressure therapy, platelet-rich plasma therapy, stem cell therapy, and biosurgery are some of the most often used supporting procedures for wound healing with these herbal drugs.
\end{abstract}

Short conclusion: There are a variety of herbal plants that have wound healing properties. This evaluation covers a wide range of plants. However, a review of the literature on diverse plants reveals that diverse chemical contents are found in different plant species, but did not mention of which chemical compounds are important for wound healing.

Keywords: Wound healing, Herbal drugs, Phases, Supporting techniques

\section{Background}

A wound may be defined as an interruption within the continuity of the epithelial lining of the skin or mucosa that occurs as a result of physical or thermal damage (Chhabra et al. 2017). Since skin is the largest organ of the human body, any obstruction in its continuity, such as a wound or a cut, compromises health and immunity. As a result, the wound must be treated as soon as possible with suitable treatment. Wound healing may be a complicated and unique process, with the changing wound

\footnotetext{
*Correspondence: jainc52@gmail.com

${ }^{1}$ Department of Pharmaceutical Chemistry, IBSS's Dr. Rajendra Gode

Institute of Pharmacy, Amravati, India

Full list of author information is available at the end of the article
}

environment in response to the overall health status of an individual (Dhivya et al. 2015).

Many conditions must come together for a superficial wound to heal, and wound dressings and coverings have changed significantly to address potential barriers to wound healing, ranging from infection to hypoxia. Even in the best of circumstances, wound tissue never recovers its pre-injury strength, and chronic non-healing wounds can be developed from several aberrant healing phases. After the certain circumstances such as trauma, either by accident or by surgery wound healing play an important role in preserves the integrity of skin (Mukty 2018; Wang et al. 2018). 


\section{Factors affecting wound healing}

Wound healing can be hampered by a variety of circumstances. The elements that affect repair are frequently divided into two categories: local and systemic. Local factors have a direct impact on the wound's features, whereas systemic factors have an impact on the individual's overall health or disease state, which influences their ability to heal. Because many of these elements are interconnected, systemic variables influence wound healing via local consequences (Guo and Dipietro 2010).

\section{Oxygenation}

For wound healing, oxygen is a very essential component. It is a complicated procedure that involves several biological processes like cell proliferation, angiogenesis, and protein synthesis, all of which are required for tissue function and integrity to be restored. Appropriate wound tissue oxygenation can affect healing responses and, in turn, the outcomes of various treatment options, depending on what the patient or physician is aiming for (Castilla et al. 2012). The effect of oxygen is dependent on the state of oxygen, such as when it is hypoxic, normal, or hyperoxic. The mitochondrial cytochrome oxidase enzyme requires oxygen during energy consumption. This produces high-energy phosphates, which are then required for a variety of cellular functions. In collagen synthesis, oxygen is implied within the hydroxylation of proline and lysine into procollagen which results in collagen development. Angiogenesis requires hypoxia to begin, but it has been demonstrated that if oxygen is used, vessel growth can be accelerated and sustained (Kimmel et al. 2016).

\section{Role of the macrophage in wound healing: (inflammation)} In wounds, macrophages perform slightly different functions, such as host defense, promoting and determining inflammation, removing apoptotic cells, and so supporting cell proliferation and tissue regeneration after injury. According to recent literature, macrophages exist in various sets of observable characteristics within the wound healing, and their impact on each step of repair differs depending on the phenotype (Gonzalez et al. 2016). As wounds heal, the local macrophage populace transitions primarily on pro-inflammatory (M1-like phenotypes) followed by anti-inflammatory (M2-like phenotypes). The chronic wound which unable to cure including pressure, arterial, venous, or diabetic ulcers indefinitely stay within inflammation. Thus, macrophages keep pro-inflammatory characteristics during wound healing (Krzyszczyk et al. 2018).

The macrophage, on the other hand, is essential for the repair of regularly healing wounds, but, in some circumstances, this pleiotropic cell type may cause excessive inflammation or fibrosis. According to new findings, macrophage dysfunction could play a role in the pathophysiology of non-healing and ineffectual healing wounds. Whereas advancements within the communication of multifunctional cells, the macrophage remains a promising therapeutic target for reducing fibrosis and scarring as well as improving chronic wound healing (Koh and DiPietro 2011; Atri et al. 2018; Leibovich and Ross 1975).

\section{Age}

In healthy people, ageing causes epithelialization to be delayed. Collagen synthesis is unaffected by ageing; however, wound non-collagenous protein deposition is reduced. In older people, this decline may compromise the mechanical qualities of scarring (Holt et al. 1992).

\section{Stress}

Stress is defined as a process in which there is an increase in external requirements of individuals perceiving capabilities to cope up with the responsibilities resulting in behavioral and physiological changes (Cohen et al. 1997). Insufficient healing enhances the complications of wound infections, extends hospital stays, intensifies patient discomfit, and slows recurrence to routine activities. Physiological stress responses can directly influence wound healing processes (Gouin and Kiecolt-Glaser 2011). The sources of stress include pain, odor, and social isolation. Uncontrollable stress has been shown in clinical studies to boost the risk of a non-healing, lower standard of life, and lead to the adoption of unhealthy habits, highlighting the significance of a multidisciplinary approach to wound healing (Wynn and Holloway 2019).

Pitiable recovery of wound is linked with unmitigated risk for wound infection and additional complications; affected person may get stress due to discomfort, prolonged sanatorium stays, and delays between one's return to regular activities. It is stated on the basis of observational, investigational, and interventional experiments that stress and other factors which affect on regular routine activities delayed the wound healing. This same phenomenon also affects on immunity (Seiler et al. 2020).

\section{Diabetes}

Diabetic foot ulceration has been a big concern in several Asian countries for decades, producing economic and social concerns. As a result, identifying and reducing diabetic foot risk factors is highly important (Xia et al. 2019). Diabetes mellitus is a complicated metabolic condition with several direct and indirect consequences on wound healing (Morain and Colen 1990). Hyperglycemia or uncontrolled glycemic levels in diabetes mellitus affect 
white blood cell function and increase the risk of infection. Diabetes also affects multiple other body systems that each one plays a task in wound healing. One example is neuropathy that develops in response to the impact of diabetes on the systema nervosum. The lack of protective feeling caused by neuropathy will limit the individual's capacity to detect changes in the extremity and, as a result, the wound, resulting in further trauma (Goodson and Hung 1977). Controlling diabetes, maintaining nutrition, and treating a systemic illness are important factors in promoting of wound healing (Yue et al. 1987).

\section{Nutrition}

Protein deficit may have a deleterious impact on the immune system as a whole, while adequate carbohydrate consumption is necessary for fibroblast migration during the proliferative phase. Vitamins A, B, C, and D, zinc, and iron, in addition to micronutrients, arginine, and glutamine, are required for the inflammatory process and collagen formation (Barchitta et al. 2019). Clinical application is achieved by ingesting a formulation containing the aforementioned nutritious components. This improves healing time, results in healthier outcomes, and reduces comorbidities (Heintschel and Heuberger 2017).

\section{Nicotine}

According to epidemiological research, smoking is a significant risk factor for the progression of a variety of chronic diseases. Nicotine, the addictive substance found in cigarettes, has potent pathophysiological effects on the human body. Although a study on the effects of cigarette smoking on corneal re-epithelialization is underway, little is known about the effects of nicotine on corneal wound healing-related neovascularization and fibrosis. Finally, we can say that chronic nicotine administration accelerated the angiogenic and fibrogenic healing processes in corneal tissue that had been alkali-burned (Kim et al. 2017).

\section{Phases of wound healing}

Following the onset of a tissue lesion, rejuvenation and tissue refurbishing processes take place, which includes a series of molecular and cellular circumstances aimed at reviving the damaged tissue. The proliferative, excreted, and extracellular matrix remodeling phases are all linked together by unique processes involving soluble mediators, blood cells, and parenchyma cells. Tissue edema is the emissive circumstance observed after the wound. The proliferative phase explores scale back of tissue damage by shrinking myofibroblasts and fibroplasia. At this phase, angiogenesis and re-epithelialization processes can quite be perceived (Gonzalez et al. 2016).
In vivo experimental studies demonstrate that wound healing occurs in four phases including acute and chronic wounds.

The phases of wound healing are as follows:

1. Hemostasis

2. Inflammation

3. Proliferation or granulation

4. Remodeling or maturation

\section{Hemostasis}

In tissue repair, the platelet is that the cell which acts because our body repairing of the off the damaged blood vessels the blood vessels get constricted in response to the damage, and the spasm get relaxed. To aid in this process, platelets emit vasoconstrictive chemicals, but their primary function is to form a stable clot that seals the injured vessel. Platelets cluster are attached to exposed collagen with the impact of adenosine diphosphate (ADP) discharged from ruptured tissues. They also release substances that interact with and promote the intrinsic coagulation cascade by assembling thrombin, which starts the synthesis of fibrin from fibrinogen. The fibrin mesh helps to form a stable hemostatic plug out of the platelet aggregation. Finally, platelets release cytokines likewise platelet-derived protein (PDGF), which is known as functional key mediators that originates subsequent processes. If there are no underlying clotting abnormalities, hemostasis occurs within minutes of the original injury (Rodrigues et al. 2019; Pool 1977; Rumbaut and Thiagarajan 2010).

The early response to a wound on the skin is vasoconstriction of the artery walls to avoid bleeding. Following that, primary and secondary hemostasis is achieved by two parallel and mechanistically connected routes. Platelet plug development is stimulated by collagen manifestation inside the subendothelial matrix in primary hemostasis. The activation of the coagulation cascade, in which soluble fibrinogen is transformed to insoluble strands that form the fibrin mesh, is referred to as secondary hemostasis. The platelet plug and fibrin mesh unite to construct a thrombus that prevents bleeding, releases complement and growth factors, and acts as a temporary scaffold for infiltrating wound healing tissue (Tennent et al. 2007; Kaplan et al. 1979; Fujiwara et al. 2013).

\section{Inflammation phase}

Inflammation is another phase of wound repair, characterized by erythema, swelling, followed by heat and all of which are accompanied by pain. This period might last up to four days after an injury. In the wound healing 
comparison, the first task after the utilities have been turned off is to clear the debris. This is a non-skilled laborer's job. The neutrophils, also known as polymorphonucleocytes (PMNs), are non-skilled workers who help heal wounds. Blood vessels become leaky as a result of the inflammatory reaction, spilling plasma, and PMNs into the surrounding tissue. Neutrophils are the first line of defense against infection, phagocytizing debris, and bacteria. They are helped by mast cells in the area. The degradation products attract the following cells engaged because fibrin is weakened as part of this cleanup. Rebuilding a home is a difficult process that necessitates the use of a project manager or a contractor. The macrophage is a cell that aids with wound healing by acting as a contractor (Millington and Norris 2000).

\section{Proliferation or granulation}

Throughout the process of proliferation, the injury is reassembling with advanced granulation tissue. This granulation tissue is consisting of collagen and extracellular matrix and a modern set of blood vessels develop this activity is said to be angiogenesis. Healthy granulation is observed when the fibroblast receiving enough level of oxygen and the required nutrition from the blood vessels. These tissues have an uneven texture. The color and state of the granulation are usually a marker of how the wound is healing. Dark granulation is often indicative of ineffective perfusion, ischemia, and infection. In the end, epithelial cells disappear from the wound which is considered as "epithelization" (Rosen 2002; Carmeliet 2003).

\section{Remodeling or maturation}

Remodeling is the ultimate stage of healing, which begins two to three weeks after the commencement of the lesion and can last a year or longer. The changing stage's main goal is to achieve maximum durability by reorganizing, degrading, and re-synthesizing the extracellular matrix. At this point in the healing process, an attempt is made to restore the typical tissue structure, and the granulation is gradually reformed, resulting in connective tissue which is least cellular and vascular, with a continuous exceeding in collagen fiber concentration (Martin 1997).

The weather has matured, resulting in deep alterations within the extracellular matrix and, as a result, the early inflammation has subsided. When a monolayer of keratinocytes covers the lesion's surface, epidermal migration stops, and a replacement stratified epidermis with a subjacent basal lamina is construct the wound linings to its interior. The matrix is being deposited and its composition is changing at this point. Type III collagen degrades as the wound heals, but type I collagen synthesis increases. During transformation, hyaluronic and fibronectin acid, which is destroyed by cells and plasmatic metalloproteinase, are depleted, increasing type I collagen expression ( Li et al. 2007).

\section{Main text}

Herbal plants and their chemical used for wound healing

Traditionally, herbal plants are widely employed for the cure different types of wounds (Sharma et al. 2021). Medicinal plants and its chemical constituents are necessary to test for its therapeutic action on wound healing. Nowadays, the era is interested toward the use of plant derivative due to less side effects. Some of the experiments showing the better progress for treatment of various wound such as diabetic, infected, and opened wounds (Farahpour 2019). For the treatment of wound, herbal crude drugs and their chemical constituents are found to be more effective in the current modern era (Shedoeva et al. 2019). Phytoconstituent present in herbal plant has the promising effect to provide improved tissue remodeling and shows its function as proangiogenic agents when employed on wounds (Thangapazham et al. 2016).

This study describes role of Aloe vera (Teplicki et al. 2018), Centella asiatica (Sh Ahmed et al. 2019), Pinus pinaster (Dogan et al. 2017), Lavandula angstiforia (Mori et al. 2016), Argania spinosa (Avsar et al. 2016), Bursera morelensis (Salas-Oropeza et al. 2020), Hypericum patulum and $H$. perforatum (Wölfle et al. 2014), Copaifera paupera (Amorim et al. 2017), Avicennia schaueriana (Lopes et al. 2019), Cucurbita pepo (Bardaa et al. 2016), Ximenia americana (Souza Neto Júnior et al. 2019), Fumaria vaillantii (Davoodi-Roodbordeii et al. 2019), Panax ginseng (Park et al. 2019), Astragali radix (Lee et al. 2018), Sauromatum guttatum (Said et al. 2019), Sapindus mukorossi (Chen et al. 2019), Euphorbia hirta (Tuhin et al. 2017), Vaccaria segetalis (Hou et al. 2020), Berula angustifolia (Sanaei et al. 2018), Pupalia lappacea (Udegbunam et al. 2014), Cydonia oblonga (Tamri et al. 2014), Ampelopsis japonica (Lee et al. 2015), Chrozophora tinctoria (Maurya et al. 2016), Nigella sativa (Sallehuddin et al. 2020), Elaeis guineensis (Sasidharan et al. 2010), Ficus racemose (Bopage et al. 2018), Sida corymbose (John-Africa et al. 2013), Blechnum orientale (Lai et al. 2011), Annona muricata (Moghadamtousi et al. 2015), Artocarpus communis (Yeh et al. 2017), Aegle marmelos (Gautam et al. 2014), Moringa oleifera (Muhammad et al. 2013), Bacopa monniera (Murthy et al. 2013), Cinnamomum verum (Daemi et al. 2019), Anacardium occidentale (da Silveira Vasconcelos et al. 2015), Ephedra alata (Kittana et al. 2017), Ficus racemose (Murti and Kumar 2012), Calotropis procera (Aderounmu et al. 2013), in wound healing. Chemical constituents present in above-mentioned plants contains glycosides, alkaloids, tannins, steroids, carbohydrates, terpenoids, carotenoids, flavonoids, 
cardenolides, vitamins, tocopherols, essential oils, resins, fatty acids; various phenolic compounds are responsible for wound healing.

Maximum plants and their chemical constituents show its effects by the mechanism by angiogenesis are NF- $\mathrm{kB}$, TGF- $\beta$, VEGF, tumor necrosis factor (TNF), and inducible nitric oxide synthase (iNOS) effect on cytokines (Thangapazham et al. 2016); apart from this different mechanism especially IL-4, IL-5, IL- 13 , and TGF- $\beta 1$, reduction in wound size by reepithelialization is also involved in wound healing.

In Table 1, the all mentioned plants are searched from the literature and their chemical constituents and mechanism by which it shows its action is explained. The chemical structure for the isolated chemical constituents present in plant is mentioned in Fig. 1.

\section{Recently developed different wound healing technique}

The most frequent wound healing treatments include hyperbaric oxygen therapy (HBOT), negative pressure therapy (NPT), platelet-rich plasma therapy (PRP), stem cell therapy (SCT), and biosurgery.

\section{Hyperbaric oxygen therapy}

Hyperbaric oxygen therapy (HBO) is an efficient supporting treatment in conditions where normal healing is damaged. In HBO 100 percent oxygen at two- to threefold, the air pressure stumped level is run and this end in arterial oxygen tension in more than $2000 \mathrm{mmHg}$ and oxygen tension in the cells of just about $400 \mathrm{mmHg}$. Such type of oxygen doses in HBR therapy has many advantages in biochemical cellular and biochemical effect (Raveenthiraraja and Manoharan 2013).

The majority of hyperbaric conditions and $\mathrm{HBO}$ therapy applications are drawn directly from physics concepts and rules evolved over millennia.

(a) Boyle's law, or the theory of compressibility, holds that the volume of a gas is inversely proportional to pressure at a constant temperature.

(b) The law of partial pressure, often termed as Dalton's law, asserts that the pressure of a gaseous mixture is equivalent to the sum of the partial pressures of its constituent gases.

(c) Henry's law describes the pathophysiology of decompression disorder and its treatment with hyperbaric oxygen.

Though HBO treatment has several drawbacks and hazards, the benefits outweigh the risks. Few disorders, such as aeroembolism and clostridial myonecrosis, have more conclusive evidence. As a result, much study must be done to determine the symptoms, medication, and duration of the treatment. Doctors must be trained to deliver this form of care, and more centers must adopt it as a routine therapy option because it has synergistic effects with other treatments (Buboltz et al. 2021).

\section{Negative pressure therapy}

Negative pressure therapy commonly referred to as topical negative pressure therapy or vacuum therapy aids wound healing. It can be used as first-line therapy for intense and composite wounds, as well as an adjuvant for time being wound closing and wound bed composition before surgical operations such as skin grafts and flap surgery. The device has a long history of widespread and successful use, even though the physiological basis of its action is still unknown, and proof-based data are slowly becoming available. Systematic analytical literature provides information on the efficacy of inducing wound healing mechanisms, particularly in the early stages. Following a review of the literature, it was discovered that it had positive efficacy in the treatment of infection. Even though this therapy appears to be beneficial and that it outperforms normal procedures, there are still some doubts about its efficacy. More prospective, randomized, blinded trials are needed since the mechanisms of action are still unknown, and since there is still a gap between evidence-based data and the great clinical outcome. When performed as directed by an expert surgeon, negative pressure therapy is a great technique for wound healing (Schintler 2012).

\section{Platelet-rich plasma therapy}

Platelet-rich plasma (PRP), also called autologous platelet gel (APG), plasma rich in growth factors (PRGF), and platelet concentrate (PC), is plasma that has been centrifuged to increase the concentration of plasma-rich platelets suspended in a small amount of plasma. Patient blood is collected during the process and centrifuged at variable speed till it is separated into three layers, viz. platelet-poor plasma (PPP), platelet-rich plasma (PRP), and red blood cells. Normally in this process, two spins are used. The primary spin is known as hard spin which separates the PPP from the red fraction and PRP. The second spin is known as soft spin which separates the red fraction from the PRP. During this process, the material having larger specific gravity will be settled down at the bottom of the tube. Directly before application, a platelet activator/agonist a mixture of topical bovine thrombin and $10 \%$ calcium chloride is included to activate the clotting cascade, producing a platelet gel. The entire operations will take near about twelve minutes to complete and produce a platelet concentration of 3-5 $\times$ that of parent plasma (Marx et al. 1998; Petrungaro 2001). 


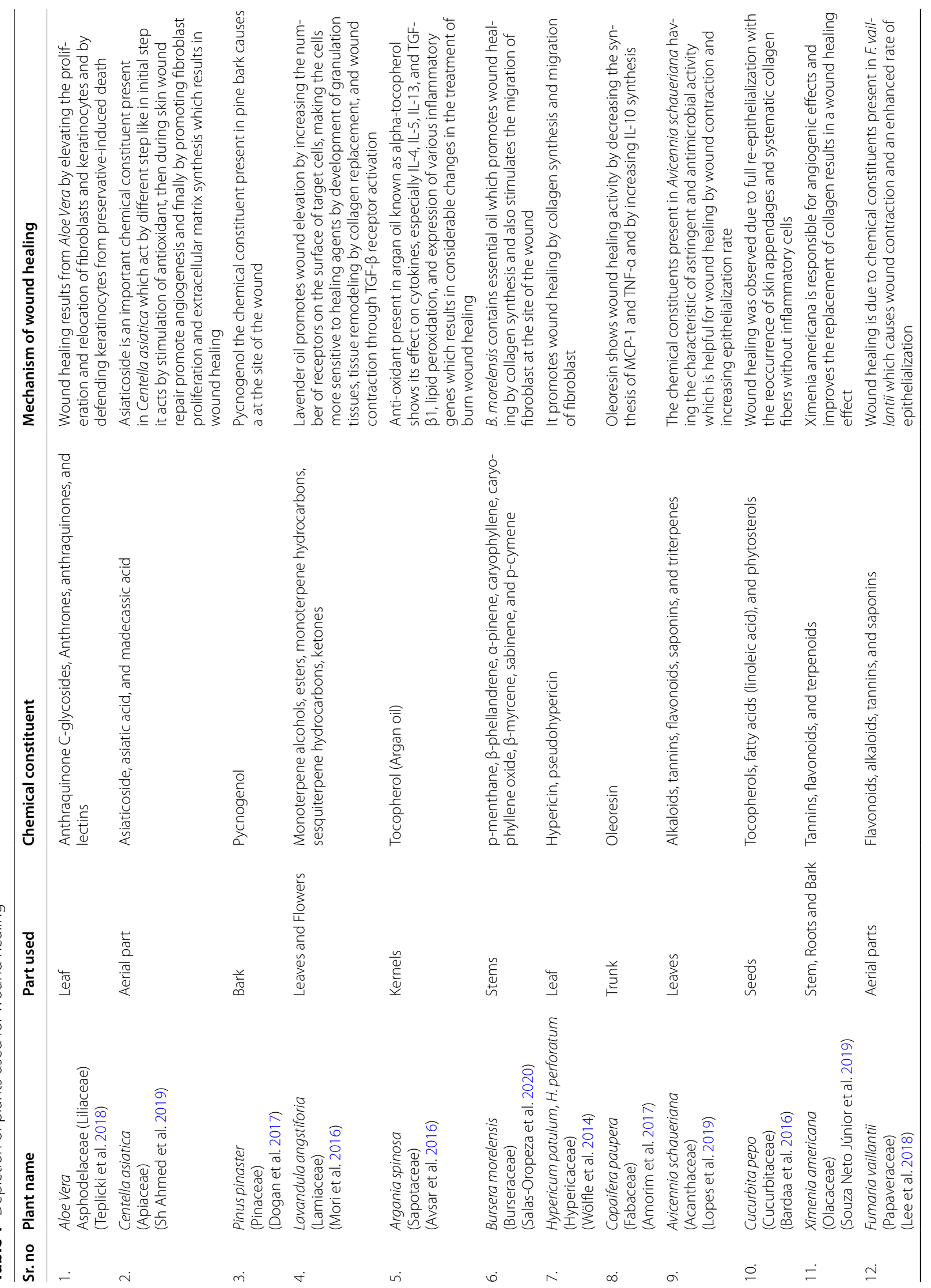




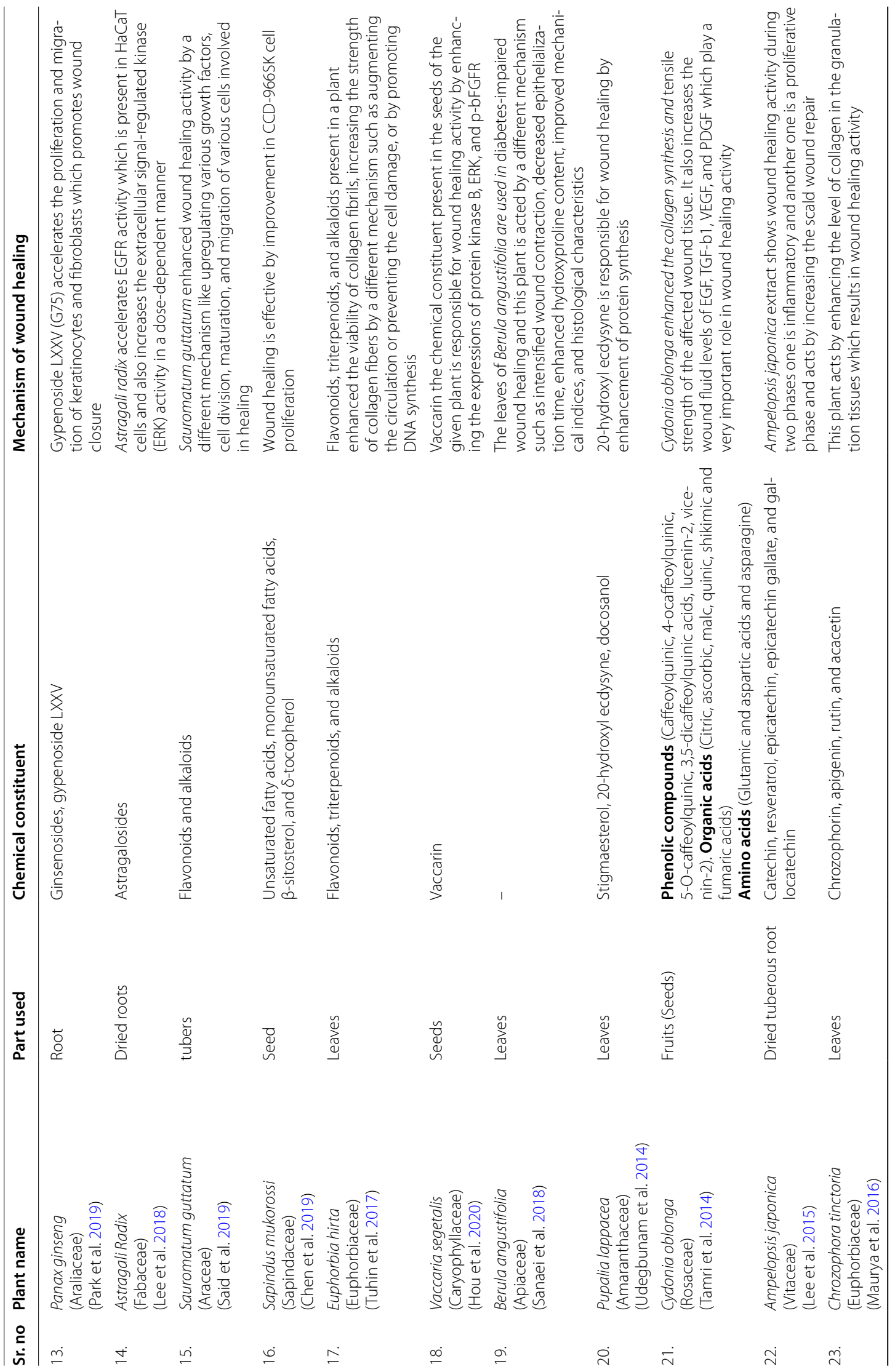




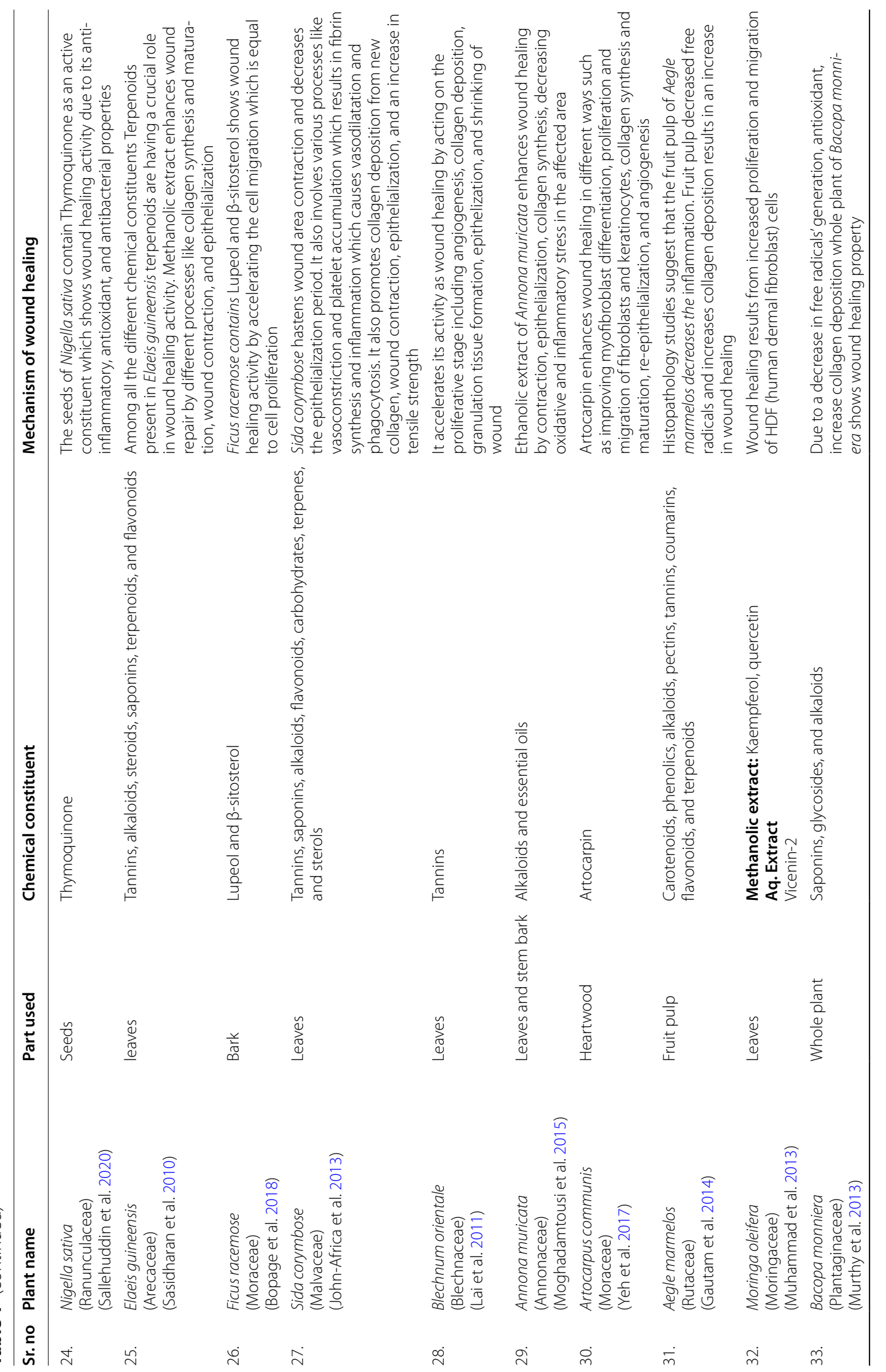




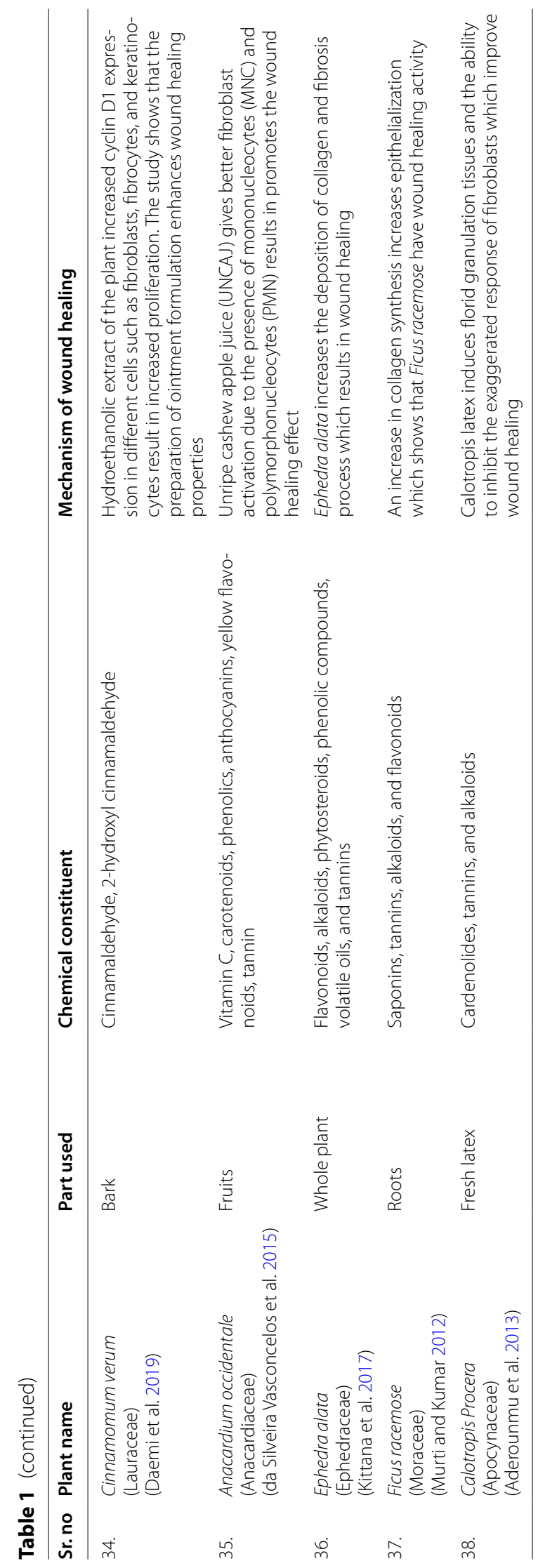


Structure of Chemical Constituents:
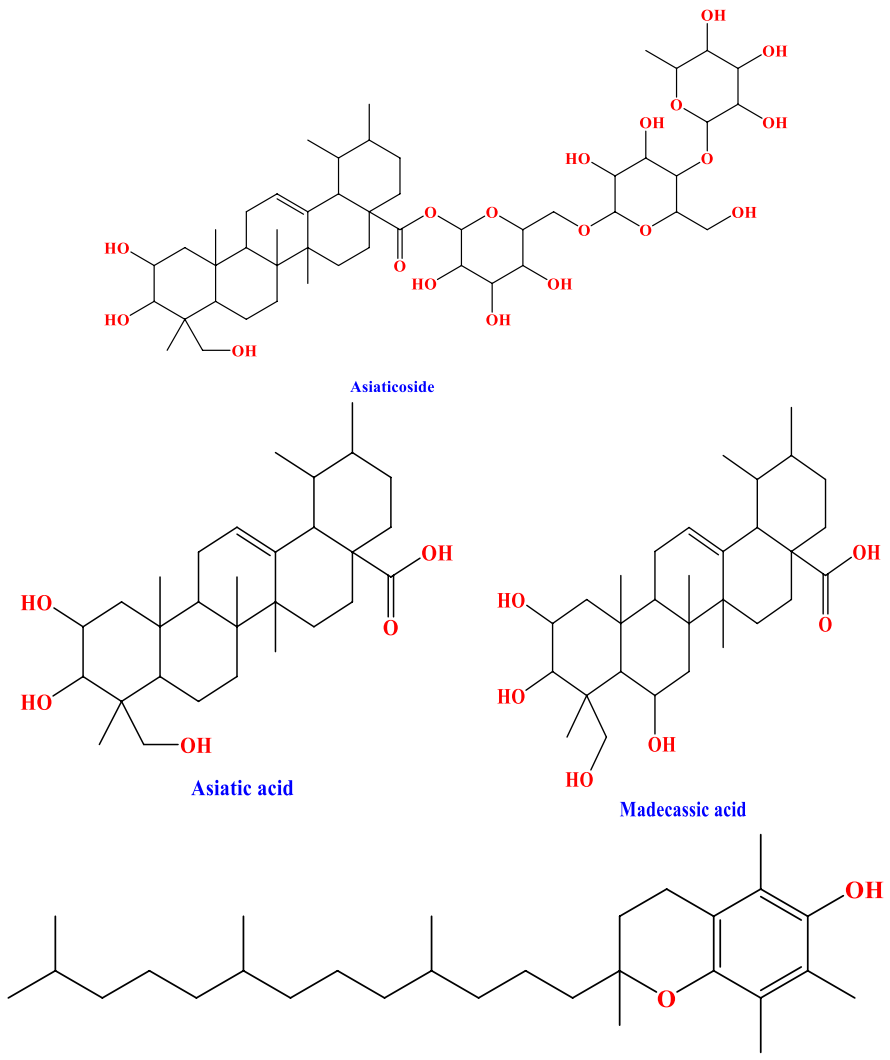

Tocopherol
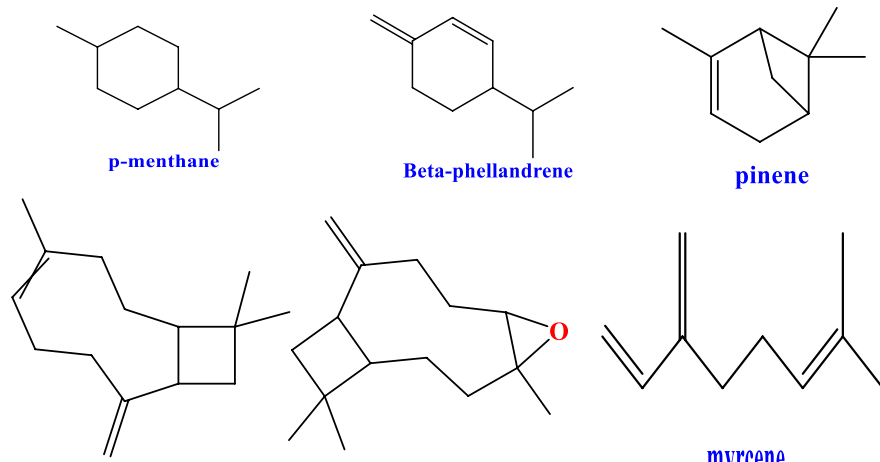

caryophyllene

caryophyllene oxide

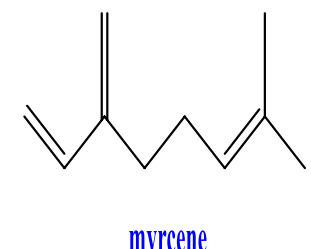

myrcene
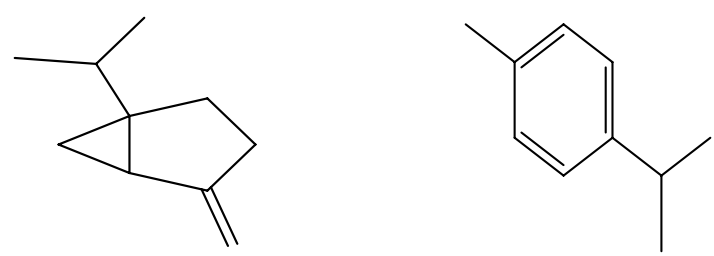

sabinene

p-cymene

Fig. 1 Chemical structures of important chemical constituents present in the plant 


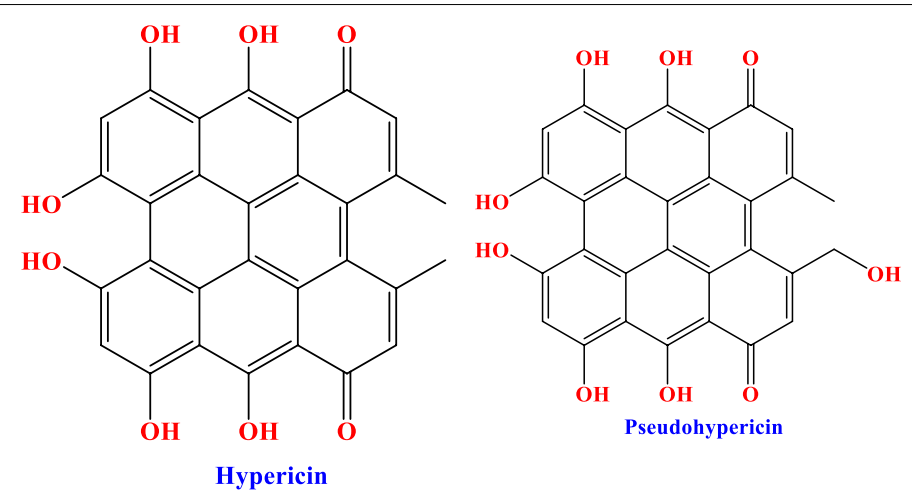<smiles>CCCCCCCCCCCCCCCCCC(=O)O</smiles><smiles>CC(C)=CCCC(C)(C)[C@H]1CCC2(C)C1CCC1C3(C)CCC(O)C(C)(C)C3CCC12C</smiles>
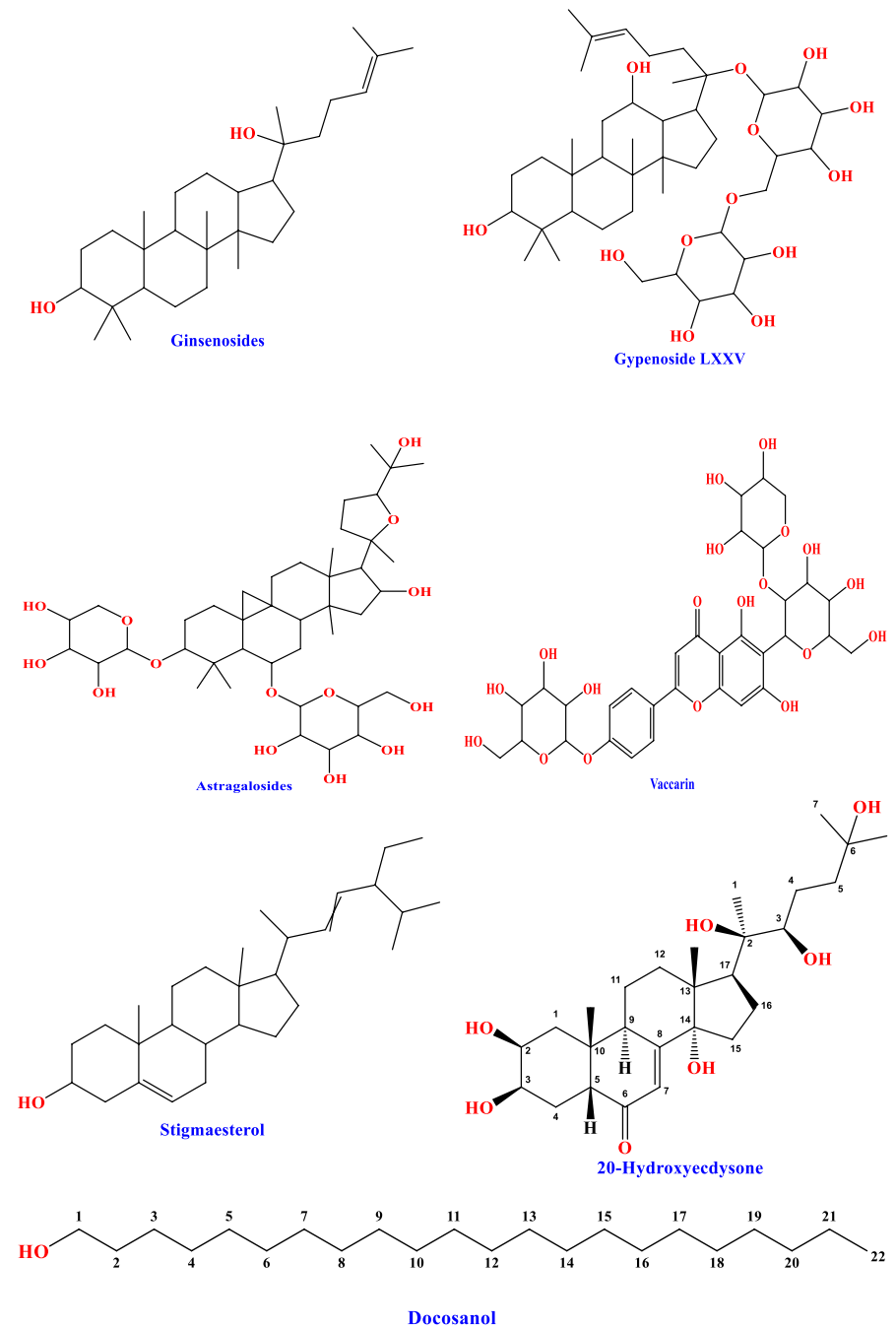

Fig. 1 continued 

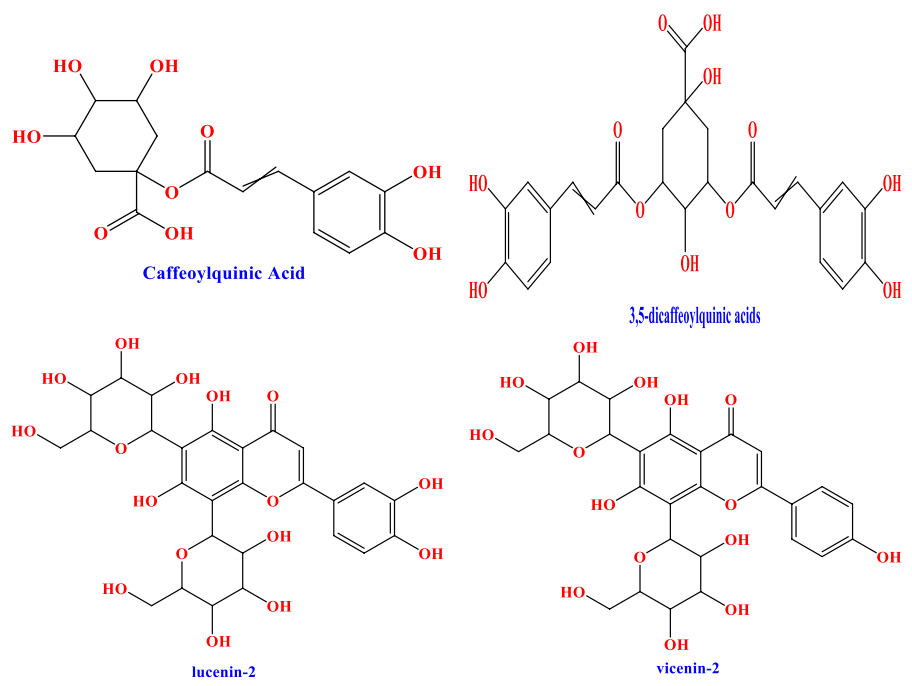<smiles>Oc1cc(O)c2c(c1)OC(c1ccc(O)c(O)c1)C(O)C2</smiles><smiles>Oc1ccc(C=Cc2cc(O)cc(O)c2)cc1</smiles><smiles>Oc1cc(O)c2c(c1)OC(c1ccc(O)c(O)c1)C(O)C2</smiles><smiles>O=C(OC1Cc2c(O)cc(O)cc2OC1c1ccc(O)c(O)c1)c1cc(O)c(O)c(O)c1</smiles><smiles>Oc1cc(O)c2c(c1)OC(c1cc(O)c(O)c(O)c1)C(O)C2</smiles><smiles>O=c1cc(-c2ccc(O)cc2)oc2cc(O)cc(O)c12</smiles>

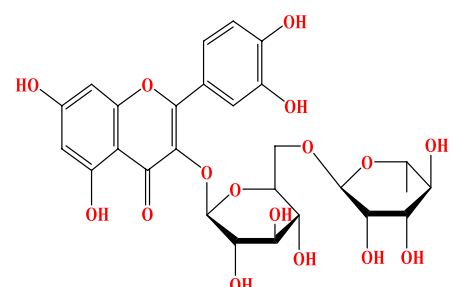<smiles>COc1ccc(-c2cc(=O)c3c(O)cc(O)cc3o2)cc1</smiles>

Fig. 1 continued Acacetin 
<smiles>CC1=CC(=O)C(C(C)C)=CC1=O</smiles>

Thymoquinone

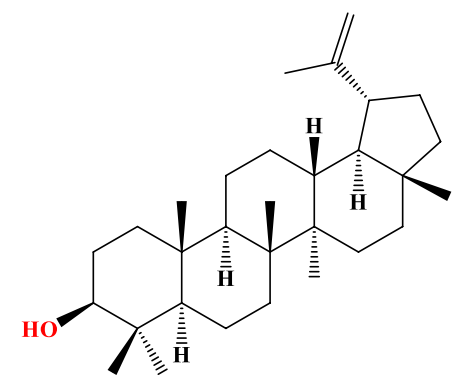

Lupeol

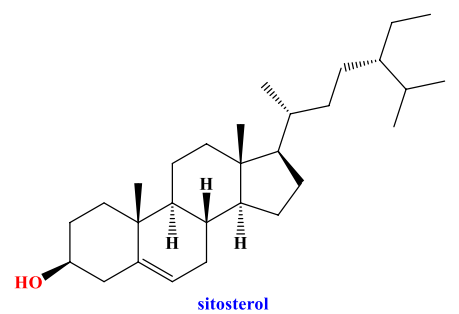<smiles>O=c1c(O)c(-c2ccc(O)cc2)oc2cc(O)cc(O)c12</smiles>

Kaempferol<smiles>O=CC=Cc1ccccc1</smiles>

Cinnamaldehyde<smiles>COc1cc2oc(-c3ccc(O)cc3O)c(CC=C(C)C)c(=O)c2c(O)c1CCC(C)C</smiles><smiles>O=c1c(O)c(-c2ccc(O)c(O)c2)oc2cc(O)cc(O)c12</smiles>

Quercetin<smiles>O=CC=Cc1ccccc1O</smiles>

2-hydroxyl cinnamaldehyde

Fig. 1 continued

Since PRP is rich in different growth factors like PDGF, VEGF, EGF, and others that are efficient to activate angiogenesis and enhance fibroblast cell differentiation, using PRP the soft tissue healing process has been introduced. It has been also proposed that PRP also speeds up the wound maturity and epithelialization which results in prevent dermis from damaged and lessen scar formation. PDGF and EGF are the important growth factors involved in fibroblast migration, proliferation, and collagen synthesis. Greater concentrations of those growth factors are likely the rationale for the fast soft tissue wound healing, which is usually recommended to be a minimum of two- to threefold rapid than that of normal (Whitman et al. 1997; Carlson and Roach 2002; Anitua et al. 2004).

\section{Stem cell therapy}

In advanced, stem cell-based therapies are mostly used for skin-regenerative and anti-fibrotic properties and effective trail on human disease. The human amniotic membrane (HAM) is considered the interior layer of the fetal membrane and is obtained from the epiblast as early as 8 days after fertilization and before gastrulation. HAM is also considered as a particular tissue which has additionally anti-inflammatory and anti-fibrotic properties. The amniotic membrane can be stored during pregnancy and has a lot of therapeutic promise due to its importance as a source of progenitor cells from the fetus's cells. Amniotic epithelial cells (AECs) and amniotic mesenchymal cells (AMCs) are the two types of stem cells that can be extracted from the AMCs. Both types of stem cells 
can self-renew and specialize into a variety of cell types. When compared to adult tissue-derived stem cells, primary human AECs have the following benefits once they are deemed majority engaging for cellular therapies: AECs are ample and can be collected without injury and expensive procedures from term placenta;

1. When contrast to embryonic stem cells, AECs have no tumor induction and no ethical limitations.

2. AECs retain the ability to develop into adipogenic, osteogenic, chondrogenic, skeletal myogenic, neurogenic, hepatic, and pancreatic lineages.

All of these studies suggest the use of AECs as a replacement anti-fibrotic therapeutic method, like reducing wound inflammation and reprogramming local cells to promote tissue regeneration and fibrosis prevention. The most essential mechanism behind the pharmacological actions of stem cells is thought to be paracrine signaling (Lai et al. 2015; Wu et al. 2017; Litwiniuk and Grzela 2014; Ding et al. 2017).

\section{Biosurgery}

Biosurgery is referred to as the use of sterile maggots, a selective technique of slough and necrotic tissue digestion from wounds without damaging the encompassing healthy tissue. Biosurgery is most feasible for wounds with slough and infection, in addition to its antibacterial impact. It is cost-effective, and it has great tolerance. There appear to be no contraindications other than the presence of fistulas and hence the wound's proximity to major blood vessels or essential organs. The deficiencies of aesthetic appeal, the less shelf-life of maggots, and more pain that occur at the wound site in certain individuals are also drawbacks (Kumar et al. 2004; Wollina et al. 2002).

\section{Conclusions}

Wounds may become a key stumbling block in our dayto-day task order in the modern human life scenario. Wound healing is influenced by a variety of factors, both local and systemic. It may result in a more stressful lifestyle. Diabetes and other significant chronic comorbidities have gotten exceedingly dangerous. A variety of allopathic medicines are available to quickly heal this condition. But, as we all know, there are some major side effects, thus individuals from all over the world are turning to herbal therapy for wound healing. There are a variety of herbal plants that have wound healing properties. This evaluation covers a wide range of plants. However, a review of the literature on diverse plants reveals that diverse chemical contents are found in different plant species, but did not mention of which chemical compounds are important for wound healing. The majority of the literature only mentions studies on extracts in various solvents that have wound healing activity, but they do not specify the chemical elements that are responsible for wound healing. So, finding chemical constituents (phytochemical screening) using various chromatographic and spectroscopic techniques and determining which chemical constituents contained in plants exhibit wound healing has a lot of potential in the future. In addition to herbal medications, wound healing procedures such as HBOT, NPT, PRP, SCT, and biosurgery are some of the most widely used. Aside from these difficulties, the development of recurrences is a key issue associated with wound healing.

\section{Abbreviations \\ ADP: Adenosine diphosphate; AEC: Amniotic epithelial cells; AMC: Amniotic mesenchymal cells; APG: Autologous platelet gel; bFGFR: Basic fibroblast growth factor receptors; DNA: Deoxyribonucleic acid; EGF: Epidermal growth factor; EGFR: Epidermal growth factor receptor; ERK: Extracellular signal- regulated kinase; HAM: Human amniotic membrane; HBOT: Hyperbaric oxygen therapy; HDF: Human dermal fibroblast; IL: Interleukin; MCP: Monocyte chemoattractant protein; MNC: Mononucleocytes; NPT: Negative pressure therapy; PC: Platelet concentrate; PDGF: Platelet-derived growth factor; PMN: Polymorphonucleocytes; PPP: Platelet-poor plasma; PRP: Platelet-rich plasma; PRGF: Plasma rich in growth factors; SCT: Stem cell therapy; TGF: Transforming growth factor; TNF: Tumor necrosis factor; UNCAJ: Unripe cashew apple juice; VEGF: Vascular endothelial growth factor.}

\section{Acknowledgements}

The authors are thankful to Hon. Yogendraji Gode, President of IBSS's Dr. Rajendra Gode Institute of Pharmacy, Amravati and Dr. Anil V. Chandewar, Principal of P. Wadhwani College of Pharmacy, Yawatmal for their permission and support for the article.

\section{Authors' contributions}

The Concept was discussed by NK while CJ prepared the writing original draft of the article followed by RB with validation and data analysis, PB contributed to data curation, $\mathrm{MJ}$ and IL checked the grammar and removed all the plagiarism, then RJ reviewed and edited the article, and finally, JM did the formal analysis of the article. All authors read and approved the final manuscript.

\section{Funding}

Not applicable.

\section{Availability of data and materials}

Data are collected from various resources such as PubMed database, google scholar, and various research journals.

\section{Declarations}

Ethics approval and consent to participate Not applicable.

\section{Consent for publication}

Not applicable.

\section{Competing interests}

The authors declare that they have no competing financial interests or personal relationships that could have appeared to influence the work reported in this paper. 


\section{Author details}

${ }^{1}$ Department of Pharmaceutical Chemistry, IBSS's Dr. Rajendra Gode Institute of Pharmacy, Amravati, India. ${ }^{2}$ Department of Pharmaceutical Chemistry, P. R. Pote Patil College of Pharmacy, Amravati, India. ${ }^{3}$ Department of Pharmacology, P. Wadhwani College of Pharmacy, Yawatmal, India. ${ }^{4}$ Department of Pharmaceutical Chemistry, IBSS's Dr. Rajendra Gode College of Pharmacy, Amravati, India. ${ }^{5}$ Department of Pharmacognosy, IBSS's Dr. Rajendra Gode College of Pharmacy, Amravati, India. ${ }^{6}$ Department of Business Administration, Faculty of Business Administration, Economics and Political Science, British University in Egypt, Cairo, Egypt.

Received: 1 November 2021 Accepted: 15 January 2022

Published online: 25 January 2022

\section{References}

Aderounmu AO, Omonisi AE, Akingbasote JA, Makanjuola M, Bejide RA, Orafidiya LO, Adelusola KA (2013) Wound-healing and potential antikeloidal properties of the latex of Calotropis procera (Aiton) Asclepiadaceae in rabbits. Afr J Tradit Complement Altern Med: AJTCAM 10(3):574-579

Amorim JL, Figueiredo JB, Amaral A, Barros E, Palmero C, MPalantinos MA, Ramos AS, Ferreira J, Silva J, Benjamim CF, Basso SL, Nasciutti LE, Fernandes PD (2017) Wound healing properties of Copaifera paupera in diabetic mice. PLOS ONE 12(10):e0187380. https://doi.org/10.1371/journ al.pone.0187380

Anitua E, Andia I, Ardanza B, Nurden P, Nurden AT (2004) Autologous platelets as a source of proteins for healing and tissue regeneration. Thromb Haemost 91(1):4-15. https://doi.org/10.1160/TH03-07-0440

Atri C, Guerfali FZ, Laouini D (2018) Role of human macrophage polarization in inflammation during infectious diseases. Int J Mol Sci 19(6):1801. https:// doi.org/10.3390/ijms19061801

Avsar U, Halici Z, Akpinar E, Yayla M, Avsar U, Harun U, Harun U, Hasan Tarik A, Bayraktutan Z (2016) The effects of argan oil in second-degree burn wound healing in rats. Ostomy Wound Manag 62(3):26-34

Barchitta M, Maugeri A, Favara G, Magnano San Lio R, Evola G, Agodi A, Basile $G$ (2019) Nutrition and wound healing: an overview focusing on the beneficial effects of Curcumin. Int J Mol Sci 20(5):1119. https://doi.org/10. 3390/ijms20051119

Bardaa S, Ben Halima N, Aloui F, Ben Mansour R, Jabeur H, Bouaziz M, Sahnoun Z (2016) Oil from pumpkin (Cucurbita pepo L.) seeds: evaluation of its functional properties on wound healing in rats. Lipids Health Dis 15:73. https://doi.org/10.1186/s12944-016-0237-0

Bopage NS, Kamal Bandara Gunaherath GM, Jayawardena KH, Wijeyaratne SC, Abeysekera AM, Somaratne S (2018) Dual function of active constituents from bark of Ficus racemosa L. in wound healing. BMC Complement Altern Med 18(1):29. https://doi.org/10.1186/s12906-018-2089-9

Buboltz JB, Murphy-Lavoie HM (2021) Gas gangrene [Updated 20 July 2021]. In: StatPearls [Internet]. Treasure Island (FL): StatPearls Publishing. https:// www.ncbi.nlm.nih.gov/books/NBK537030/

Carlson NE, Roach RB Jr (2002) Platelet-rich plasma: clinical applications in dentistry. J Am Dent Assoc 133(10):1383-1386. https://doi.org/10.14219/ jada.archive.2002.0054

Carmeliet P (2003) Angiogenesis in health and disease. Nat Med 9(6):653-660. https://doi.org/10.1038/nm0603-653

Castilla DM, Liu ZJ, Velazquez OC (2012) Oxygen: implications for wound healing. Adv Wound Care 1(6):225-230. https://doi.org/10.1089/wound. 2011.0319

Chen CC, Nien CJ, Chen LG, Huang KY, Chang WJ, Huang HM (2019) Effects of Sapindus mukorossi seed oil on skin wound healing: in vivo and in vitro testing. Int J Mol Sci 20(10):2579. https://doi.org/10.3390/ijms20102579

Chhabra S, Chhabra N, Kaur A, Gupta N (2017) Wound healing concepts in clinical practice of OMFS. J Maxillofac Oral Surg 16(4):403-423. https:// doi.org/10.1007/s12663-016-0880-z

Cohen S, Kessler RC, Gordon LU (eds) (1997) Measuring stress: a guide for health and social scientists. Oxford University Press on Demand, Oxford

da Silveira Vasconcelos M, Gomes-Rochette NF, de Oliveira ML, Nunes-Pinheiro DC, Tomé AR, Maia de Sousa FY, Pinheiro FG, Moura CF, Miranda MR, Mota EF, de Melo DF (2015) Anti-inflammatory and wound healing potential of cashew apple juice (Anacardium occidentale L.) in mice. Exp Biol Med 240(12):1648-1655. https://doi.org/10.1177/1535370215576299

Daemi A, Lotfi M, Farahpour MR, Oryan A, Ghayour SJ, Sonboli A (2019) Topical application of Cinnamomum hydroethanolic extract improves wound healing by enhancing re-epithelialization and keratin biosynthesis in streptozotocin-induced diabetic mice. Pharm Biol 57(1):799-806. https:// doi.org/10.1080/13880209.2019.1687525

Davoodi-Roodbordeii F, Afshar M, Haji Abas Tabrizi F, Choopani S, Torkaman G, Moayer F, Salimi M (2019) Topical hydrogel containing Fumaria vaillantii Loisel. extract enhances wound healing in rats. BMC Complement Altern Med 19(1):254. https://doi.org/10.1186/s12906-019-2645-y

Dhivya S, Padma WV, Santhini E (2015) Wound dressings-a review. Biomedicine 5(4):22. https://doi.org/10.7603/s40681-015-0022-9

Ding S, Kumar S, Mok PL (2017) Cellular reparative mechanisms of mesenchymal stem cells for retinal diseases. Int J Mol Sci 18(8):1406. https://doi.org/ 10.3390/ijms18081406

Dogan E, Yanmaz L, Gedikli S, Ersoz U, Okumus Z (2017) The effect of pycnogenol on wound healing in diabetic rats. Ostomy Wound Manag 63(4):41-47

Farahpour MR (2019) Medicinal plants in wound healing. In: Wound healingcurrent perspectives. Kamil Hakan Dogan, pp 33-47. https://doi.org/10. 5772/intechopen.80215

Fujiwara T, Kubo T, Kanazawa S, Shingaki K, Taniguchi M, Matsuzaki S, Gurtner GC, Tohyama M, Hosokawa K (2013) Direct contact of fibroblasts with neuronal processes promotes differentiation to myofibroblasts and induces contraction of collagen matrix in vitro. Wound Repair Regen 21(4):588-594. https://doi.org/10.1111/wrr.12059

Gautam MK, Purohit V, Agarwal M, Singh A, Goel RK (2014) In vivo healing potential of Aegle marmelos in excision, incision, and dead space wound models. Sci World J 2014:740107. https://doi.org/10.1155/2014/740107

Gonzalez AC, Costa TF, Andrade ZA, Medrado AR (2016) Wound healing-a literature review. An Bras Dermatol 91(5):614-620. https://doi.org/10. 1590/abd1806-4841.20164741

Goodson WH III, Hung TK (1977) Studies of wound healing in experimental diabetes mellitus. J Surg Res 22(3):221-227. https://doi.org/10.1016/00224804(77)90137-8

Gouin JP, Kiecolt-Glaser JK (2011) The impact of psychological stress on wound healing: methods and mechanisms. Immunol Allergy Clin N Am 31(1):81-93. https://doi.org/10.1016/j.iac.2010.09.010

Guo S, Dipietro LA (2010) Factors affecting wound healing. J Dent Res 89(3):219-229. https://doi.org/10.1177/0022034509359125

Heintschel M, Heuberger R (2017) The potential role of zinc supplementation on pressure injury healing in older adults: a review of the literature. Wounds Compend Clin Res Pract 29(2):56-61

Holt DR, Kirk SJ, Regan MC, Hurson M, Lindblad WJ, Barbul A (1992) Effect of age on wound healing in healthy human beings. Surgery 112(2):293-298

Hou B, Cai W, Chen T, Zhang Z, Gong H, Yang W, Qiu L (2020) Vaccarin hastens wound healing by promoting angiogenesis via activation of MAPK/ERK and PI3K/AKT signaling pathways in vivo. Acta Cir Bras 34(12):e201901202. https://doi.org/10.1590/s0102-865020190120000002

John-Africa LB, Yahaya TA, Isimi CY (2013) Anti-ulcer and wound healing activities of Sida corymbosa in rats. Afr J Tradit Complement Altern Med: AJTCAM 11(1):87-92

Kaplan KL, Broekman MJ, Chernoff A, Lesznik GR, Drillings M (1979) Platelet alpha-granule proteins: studies on release and subcellular localization. Blood 53(4):604-618

Kim JW, Lim CW, Kim B (2017) Effects of nicotine on corneal wound healing following acute alkali burn. PLoS ONE 12(6):e0179982. https://doi.org/10. 1371/journal.pone.0179982

Kimmel HM, Grant A, Ditata J (2016) The presence of oxygen in wound healing. Wounds Compend Clin Res Pract 28(8):264-270

Kittana N, Abu-Rass H, Sabra R, Manasra L, Hanany H, Jaradat N, Hussein F, Zaid AN (2017) Topical aqueous extract of Ephedra alata can improve wound healing in an animal model. Chin J Trauma = Zhonghua Chuang Shang Za Zhi 20(2):108-113. https://doi.org/10.1016/j.cjtee.2016.10.004

Koh TJ, DiPietro LA (2011) Inflammation and wound healing: the role of the macrophage. Expert Rev Mol Med 13:e23. https://doi.org/10.1017/S1462 399411001943

Krzyszczyk P, Schloss R, Palmer A, Berthiaume F (2018) The role of macrophages in acute and chronic wound healing and interventions to 
promote pro-wound healing phenotypes. Front Physiol 9:419. https://doi. org/10.3389/fphys.2018.00419

Kumar S, Wong PF, Leaper DJ (2004) What is new in wound healing? Turk J Med Sci 34(3):147-160

Lai HY, Lim YY, Kim KH (2011) Potential dermal wound healing agent in Blechnum orientale Linn. BMC Complement Altern Med 11:62. https://doi.org/ 10.1186/1472-6882-11-62

Lai D, Wang Y, Sun J, Chen Y, Li T, Wu Y, Guo L, Wei C (2015) Derivation and characterization of human embryonic stem cells on human amnion epithelial cells. Sci Rep 5:10014. https://doi.org/10.1038/srep10014

Lee K, Lee B, Lee MH, Kim B, Chinannai KS, Ham I, Choi HY (2015) Effect of Ampelopsis Radix on wound healing in scalded rats. BMC Complement Altern Med 15:213. https://doi.org/10.1186/s12906-015-0751-z

Lee SY, Chang WL, Li ZX, Kirkby NS, Tsai WC, Huang SF, Ou CH, Chang TC (2018) Astragaloside VI and cycloastragenol-6-O-beta-D-glucoside promote wound healing in vitro and in vivo. Phytomedicine 38:183-191. https:// doi.org/10.1016/.jphymed.2017.12.003

Leibovich SJ, Ross R (1975) The role of the macrophage in wound repair. A study with hydrocortisone and antimacrophage serum. Am J Pathol 78(1):71-100

Li J, Chen J, Kirsner R (2007) Pathophysiology of acute wound healing. Clin Dermatol 25(1):9-18. https://doi.org/10.1016/j.clindermatol.2006.09.007

Litwiniuk M, Grzela T (2014) Amniotic membrane: new concepts for an old dressing. Wound Repair Regen 22(4):451-456. https://doi.org/10.1111/ wrr. 12188

Lopes C, Baratella-Evêncio L, Souza IA, Oliveira EB, Sá J, Santana M, Marcelino Neto PP, Santana ES, Silva L, Vieira J (2019) Evaluation of cytotoxicity and wound healing activity of Avicennia schaueriana in cream. An Acad Bras Cienc 91(1):e20180171. https://doi.org/10.1590/0001-3765201920180171

Martin P (1997) Wound healing-aiming for perfect skin regeneration. Science (New York, N.Y.) 276(5309):75-81. https://doi.org/10.1126/science.276. 5309.75

Marx RE, Carlson ER, Eichstaedt RM, Schimmele SR, Strauss JE, Georgeff KR (1998) Platelet-rich plasma: growth factor enhancement for bone grafts. Oral Surg Oral Med Oral Pathol Oral Radiol Endod 85(6):638-646. https:// doi.org/10.1016/s1079-2104(98)90029-4

Maurya H, Semwal M, Dubey SK (2016) Pharmacological evaluation of Chrozophora tinctoria as wound healing potential in diabetic rat's model. Biomed Res Int 2016:7475124. https://doi.org/10.1155/2016/7475124

Millington JT, Norris TW (2000) Effective treatment strategies for diabetic foot wounds. J Fam Pract 49(11 Suppl):S40-S48

Moghadamtousi SZ, Rouhollahi E, Hajrezaie M, Karimian H, Abdulla MA, Kadir HA (2015) Annona muricata leaves accelerate wound healing in rats via involvement of Hsp70 and antioxidant defence. Int J Surg (London, England) 18:110-117. https://doi.org/10.1016/j.ijsu.2015.03.026

Morain WD, Colen LB (1990) Wound healing in diabetes mellitus. Clin Plast Surg 17(3):493-501

Mori HM, Kawanami H, Kawahata H, Aoki M (2016) Wound healing potential of lavender oil by acceleration of granulation and wound contraction through induction of TGF- $\beta$ in a rat model. BMC Complement Altern Med 16:144. https://doi.org/10.1186/s12906-016-1128-7

Muhammad AA, Pauzi NA, Arulselvan P, Abas F, Fakurazi S (2013) In vitro wound healing potential and identification of bioactive compounds from Moringa oleifera Lam. Biomed Res Int 2013:974580. https://doi.org/10. $1155 / 2013 / 974580$

Mukty S (2018) Advance measures and challenges of wound healing. J Pharmacol Ther Res 2(1):1-3. https://doi.org/10.35841/pharmacology.2.1.1-3

Murthy S, Gautam MK, Goel S, Purohit V, Sharma H, Goel RK (2013) Evaluation of in vivo wound healing activity of Bacopa monniera on different wound model in rats. Biomed Res Int 2013:972028. https://doi.org/10.1155/2013/ 972028

Murti K, Kumar U (2012) Enhancement of wound healing with roots of Ficus racemosa L. in albino rats. Asian Pac J Trop Biomed 2(4):276-280. https:// doi.org/10.1016/S2221-1691(12)60022-7

Park S, Ko E, Lee JH, Song Y, Cui CH, Hou J, Jeon BM, Kim HS, Kim SC (2019) Gypenoside LXXV promotes cutaneous wound healing in vivo by enhancing connective tissue growth factor levels via the glucocorticoid receptor pathway. Molecules (Basel, Switzerland) 24(8):1595. https://doi. org/10.3390/molecules24081595
Petrungaro PS (2001) Using platelet-rich plasma to accelerate soft tissue maturation in esthetic periodontal surgery. Compend Contin Educ Dent (Jamesburg, N.J.: 1995) 22(9):729-746

Pool JG (1977) Normal hemostatic mechanisms: a review. Am J Med Technol 43(8):776-780

Raveenthiraraja T, Manoharan S (2013) Hyperbaric oxygen therapy: a review. Int J Pharm Pharm Sci 5:52-54

Rodrigues M, Kosaric N, Bonham CA, Gurtner GC (2019) Wound healing: a cellular perspective. Physiol Rev 99(1):665-706. https://doi.org/10.1152/ physrev.00067.2017

Rosen BP (2002) Biochemistry of arsenic detoxification. FEBS Lett 529(1):86-92. https://doi.org/10.1016/s0014-5793(02)03186-1

Rumbaut RE, Thiagarajan P (2010) Platelet-vessel wall interactions in hemostasis and thrombosis. Morgan Claypool Life Sci. https://doi.org/10.4199/ C00007ED1V01Y201002ISP004

Said A, Wahid F, Bashir K, Rasheed HM, Khan T, Hussain Z, Siraj S (2019) Sauromatum guttatum extract promotes wound healing and tissue regeneration in a burn mouse model via up-regulation of growth factors. Pharm Biol 57(1):736-743. https://doi.org/10.1080/13880209.2019.1676266

Salas-Oropeza J, Jimenez-Estrada M, Perez-Torres A, Castell-Rodriguez AE, Becerril-Millan R, Rodriguez-Monroy MA, Canales-Martinez MM (2020) Wound healing activity of the essential oil of Bursera morelensis, in mice. Molecules (Basel, Switzerland) 25(8):1795. https://doi.org/10.3390/molec ules 25081795

Sallehuddin N, Nordin A, Bt Hj Idrus R, Fauzi MB (2020) Nigella sativa and its active compound, thymoquinone, accelerate wound healing in an in vivo animal model: a comprehensive review. Int J Environ Res Public Health 17(11):4160. https://doi.org/10.3390/ijerph17114160

Sanaei N, Mohammadi R, Raisi A, Zarei L (2018) Extract of Berula angustifolia (L.) mertens enhances wound healing in streptozotocin-induced diabetic rats. Wounds Compend Clin Res Pract 30(8):242-248

Sasidharan S, Nilawatyi R, Xavier R, Latha LY, Amala R (2010) Wound healing potential of Elaeis guineensis Jacq leaves in an infected albino rat model. Molecules (Basel, Switzerland) 15(5):3186-3199. https://doi.org/10.3390/ molecules15053186

Schintler MV (2012) Negative pressure therapy: theory and practice. Diabetes Metab Res Rev 28(Suppl 1):72-77. https://doi.org/10.1002/dmrr.2243

Seiler A, Fagundes CP, Christian LM (2020) The impact of everyday stressors on the immune system and health. In: Choukèr A (ed) Stress challenges and immunity in space. Springer, Cham, pp 71-92

Sh Ahmed A, Taher M, Mandal UK, Jaffri JM, Susanti D, Mahmood S, Zakaria ZA (2019) Pharmacological properties of Centella asiatica hydrogel in accelerating wound healing in rabbits. BMC Complement Altern Med 19(1):213. https://doi.org/10.1186/s12906-019-2625-2

Sharma A, Khanna S, Kaur G, Singh I (2021) Medicinal plants and their components for wound healing applications. Future J Pharm Sci 7(1):1-13

Shedoeva A, Leavesley D, Upton Z, Fan C (2019) Wound healing and the use of medicinal plants. Evid Based Complement Altern Med: Ecam 2019:2684108. https://doi.org/10.1155/2019/2684108

Sinha M (2018) Advance measures and challenges of wound healing. J Pharmacol Ther Res 2(1):1-3

Souza Neto Júnior JC, Estevão L, Ferraz AA, Simões RS, Vieira M, Evêncio-Neto J (2019) Ointment of Ximenes americana promotes acceleration of wound healing in rats1. Acta Cir Bras 34(3):e201900307. https://doi.org/10.1590/ s0102-865020190030000007

Tamri P, Hemmati A, Boroujerdnia MG (2014) Wound healing properties of quince seed mucilage: in vivo evaluation in rabbit full-thickness wound model. Int J Surg (London, England) 12(8):843-847. https://doi.org/10. 1016/j.ijsu.2014.06.016

Tennent GA, Brennan SO, Stangou AJ, O’Grady J, Hawkins PN, Pepys MB (2007) Human plasma fibrinogen is synthesized in the liver. Blood 109(5):19711974. https://doi.org/10.1182/blood-2006-08-040956

Teplicki E, Ma Q, Castillo DE, Zarei M, Hustad AP, Chen J, Li J (2018) The effects of Aloevera on wound healing in cell proliferation, migration, and viability. Wounds Compend Clin Res Pract 30(9):263-268

Thangapazham RL, Sharad S, Maheshwari RK (2016) Phytochemicals in wound healing. Adv Wound Care 5(5):230-241. https://doi.org/10.1089/wound. 2013.0505

Tuhin RH, Begum MM, Rahman MS, Karim R, Begum T, Ahmed SU, Mostofa R, Hossain A, Abdel-Daim M, Begum R (2017) Wound healing effect of Euphorbia hirta Linn. (Euphorbiaceae) in alloxan induced diabetic 
rats. BMC Complement Altern Med 17(1):423. https://doi.org/10.1186/ s12906-017-1930-X

Udegbunam SO, Udegbunam RI, Muogbo CC, Anyanwu MU, Nwaehujor CO (2014) Wound healing and antibacterial properties of methanolic extract of Pupalia lappacea Juss in rats. BMC Complement Altern Med 14:157. https://doi.org/10.1186/1472-6882-14-157

Wang PH, Huang BS, Horng HC, Yeh CC, Chen YJ (2018) Wound healing. J Chin Med Assoc: JCMA 81(2):94-101. https://doi.org/10.1016/j.jcma.2017.11. 002

Whitman DH, Berry RL, Green DM (1997) Platelet gel: an autologous alternative to fibrin glue with applications in oral and maxillofacial surgery. J Oral Maxillofac Surg 55(11):1294-1299. https://doi.org/10.1016/s02782391(97)90187-7

WöIfle U, Seelinger G, Schempp CM (2014) Topical application of St. John's wort (Hypericum perforatum). Planta Med 80(2-3):109-120. https://doi. org/10.1055/s-0033-1351019

Wollina U, Liebold K, Schmidt WD, Hartmann M, Fassler D (2002) Biosurgery supports granulation and debridement in chronic wounds-clinical data and remittance spectroscopy measurement. Int J Dermatol 41(10):635639. https://doi.org/10.1046/j.1365-4362.2002.01354.x

Wu Q, Fang T, Lang H, Chen M, Shi P, Pang X, Qi G (2017) Comparison of the proliferation, migration and angiogenic properties of human amniotic epithelial and mesenchymal stem cells and their effects on endothelial cells. Int J Mol Med 39(4):918-926. https://doi.org/10.3892/ijmm.2017. 2897

Wynn M, Holloway S (2019) The impact of psychological stress on wound healing: a theoretical and clinical perspective. Wounds UK 15(3):20-27

Xia N, Morteza A, Yang F, Cao H, Wang A (2019) Review of the role of cigarette smoking in diabetic foot. J Diabetes Investig 10(2):202-215. https://doi. org/10.1111/jdi.12952

Yeh CJ, Chen CC, Leu YL, Lin MW, Chiu MM, Wang SH (2017) The effects of artocarpin on wound healing: in vitro and in vivo studies. Sci Rep 7(1):15599. https://doi.org/10.1038/s41598-017-15876-7

Yue DK, McLennan S, Marsh M, Mai YW, Spaliviero J, Delbridge L, Reeve T, Turtle JR (1987) Effects of experimental diabetes, uremia, and malnutrition on wound healing. Diabetes 36(3):295-299. https://doi.org/10.2337/diab. 36.3.295

\section{Publisher's Note}

Springer Nature remains neutral with regard to jurisdictional claims in published maps and institutional affiliations.

\section{Submit your manuscript to a SpringerOpen ${ }^{\circ}$ journal and benefit from:}

- Convenient online submission

- Rigorous peer review

- Open access: articles freely available online

- High visibility within the field

- Retaining the copyright to your article

Submit your next manuscript at $\boldsymbol{\nabla}$ springeropen.com 